Kinestetik : Jurnal Ilmiah Pendidikan Jasmani 5 (4) (2021)

Kinestetik : Jurnal Ilmiah Pendidikan Jasmani

https://ejournal.unib.ac.id/index.php/kinestetik/index

DOI : $10.33369 / j k . v 5 i 4.19723$

\title{
ADOBE FLASH APPLICATION TO IMPROVE LEARNING OUTCOMES OF HANDBALL COURSES FOR STUDENTS OF PHYSICAL EDUCATION STUDY PROGRAM FKIP UNIB
}

Yarmani $^{1}$, Syafrial ${ }^{2}$, Bogy Restu Ilahi*3 ${ }^{3}$, Defliyanto ${ }^{4}$

${ }^{1234}$ Prodi Pendidikan Jasmani, Fakultas Keguruan dan Ilmu Pendidikan, , Bengkulu, Indonesia

\section{Article Info}

Article History :

Received : December 2021

Revised : December 2021

Accepted : December 2021

Available online : December 2021

Keywords:

Adobe Flash, Handball, Learning
Abstract

Research on Adobe Flash Applications To Improve Learning Outcomes of Handball Courses for Students of Physical Education Study Program FKIP UNIB aims to improve learning outcomes in handball courses as well as to determine the effectiveness of Adobe applications in learning handball. The method used in this study is (Classroom Action Research), the results of this study are descriptive because in this study a description will be produced about the extent to which handball learning has been improved by using Adobe Flash in physical education students of FKIP UNIB. The sample of this research is the third semester students of Physical Education Study Program, totaling 24 people. The data analysis technique used in this study is descriptive statistics in the form of percentages presented in tables or graphs. The results of this study are that students can improve learning outcomes in handball courses. This can be seen from the percentage results which show that at the time of the pre-cycle an average score of 62.50 was obtained, with 7 students getting a complete score of $29 \%$. In the first cycle, the average score was 67.10 with 12 people completing the $50 \%$ percentage. And in the second cycle showed significant results with completeness reaching 21 students out of 24 students getting a percentage of $87.5 \%$. From these results it shows that student learning outcomes increase after learning using Adobe Flash is applied.
Corresponding address : Jl. Raden Fatah No. 100 Kota Bengkulu

*Corresponding email : bogyrestu@unib.ac.id
ISSN 2685-6514 (Online)

ISSN 2477-331X (Print) 


\section{INTRODUCTION}

S1 Physical Education Study Program FKIP Unib has one of the mandatory courses, namely the Handball Orpillar course with a weight of 2 credits. This Preferred Sport (Orpil) is given in the odd semester (III) with learning outcomes, namely students are able to know and understand and carry out handball sports properly and correctly. Handball itself has basic techniques that must be developed so as to create a good quality game. The techniques in playing handball are: Dribbling, Passing, Catch, and Shooting.

In the observation of the learning of the handball course, it was shown that most of the students of the Physical Education Study Program FKIP UNIB were still unfamiliar with the game of handball. In addition, some students tend to emphasize scoring activities rather than implementing quality games through the implementation of Handball playing exercises. This is of course worrying because the main purpose of the handball course is for students to be able to carry out handball sports well so as to create quality games. However, the facts that occurred during the observation showed that most of the students of Physical Education Study Program FKIP Unib during the handball game tended to lose and while dribbling. This shows that for basic handball technique training, students tend to be weak, especially during the current Covid-19 pandemic, they have to self-isolate at home by doing
Physical Distancing (Keeping Distance) for an undecided time.

Therefore, an online learning strategy is needed to improve the quality of learning outcomes in handball courses while staying at home.

Based on the results of these conditions, the team teaching of the Orpil Handball course, Physical Education Study Program, FKIP Unib held a discussion that resulted in a reflection on the need for classroom action research by implementing interesting and innovative learning methods based on online systems in order to improve students' basic handball technique skills and ultimately maximize learning outcomes in handball courses. The learning strategy that is expected to improve the quality of student handball learning in the handball game is through the Adobe Flash application.

Adobe Flash application is an online application by stimulating students to move according to programmed instructions and being able to create or make a movement that will be practiced or will be researched. then the use of the Adobe Flash Application as a learning method can be effectively used in handball course training during the Covid-19 pandemic which requires Stay At Home.

\section{METHODS}

This research is Classroom Action Research, which is an action research within the scope of education and training conducted by researchers, and at the same time as researchers in their class or 
together with other people (collaboration) by designing, implementing, and reflecting on actions collectively. collaborative and participatory which aims to improve or improve the quality (quality) of the learning process in the class through a certain action (treatment) in a cycle (Sugiono, 2011)

This study uses a descriptive method because in this study a description will be produced about the extent to which handball learning has been improved by using Adobe Flash for the physical education students of Fkip Unib as the research sample. The application of the blended learning method using the Adobe Flash application in the Handball course allows students to have increased learning outcomes so that they will get the desired results and results can be achieved.

(Sugiyono, 2018) states that the population is a generalization area division consisting of objects/subjects that have certain characteristics and are in accordance with those determined by the researcher so that the researcher can then draw conclusions from these data. The population in this study were students who took handball lectures in the odd semester of the Physical Education Study Program, FKIP UNIB.

Research instrument is a tool used to collect research data. The instrument used is an observation sheet. In addition, the instrument in this study is also an assessment guide sheet. The data analysis technique used in this study is descriptive statistics in the form of percentages presented in tables or graphs. The categories in the data will be adjusted to the existing percentages. The following is the formula that will be used in data processing.

Tabel 1. Rating Category

\begin{tabular}{ccc}
\hline No & Percentage & Category \\
\hline 1 & $80 \%-100 \%$ & Very Good (A) \\
\hline 2 & $70 \%-79 \%$ & Good (B) \\
\hline 3 & $60 \%-69 \%$ & passable (C) \\
\hline 4 & $45 \%-59 \%$ & Not good (D)
\end{tabular}

\section{Procedures}

This classroom action research plan will be implemented in two cycles, and each cycle consists of four stages, namely: 1) planning stage, 2) actuating, 3) observing (observing), and 4) reflection (reflecting).

Cycle 1

1. Planning Stage

At the planning stage, the preparation of learning tools needed during the teaching and learning process is carried out, including: (1) preparing a Research Design, (2) preparing material in the form of videos that will be shared,

(1) Provide instructions for students to download the Adobe Flash application and learn how it works (4) prepare an observation sheet containing basic questions regarding techniques for improving handball skills as a pre-action instrument to determine the percentage of student knowledge,

(2) prepare a list of activities in the implementation of Adobe Flash as a guide in action research.

2. Implementation Stage

This stage is the implementation of the learning scenarios that have been made in the previous stage in the classroom, including:

1) Initial activities

a. The researcher conditions the class (greetings, praying, filling out journals, presenting and attending students through the Adobe Flash application) 
b. Researchers convey research objectives c. Meeting 1, the researcher carried out pre-action activities by giving students basic questions about the basic techniques of handball as a pre-action instrument to determine the percentage of initial knowledge about passing, dribbling, shooting, heading techniques.

d. Meeting 2, based on the results of the pre-action, the researcher explained about the implementation of the Adobe Flash Method in improving handball learning outcomes.

2) Core Activities

a. Meeting 3, the researcher explained the training technique material through videos that had been shared via email in the form of technical guidelines about the Adobe Flash application

b. Participants implement the Adobe Flash Method with the techniques that have been given previously based on the prepared RPS.

3) Final activity

a. Participants make conclusions about the learning process they have followed

b. Researchers provide reinforcement to the conclusions that have been submitted by participants.

3. Observation stage

At the time of implementation, the research team also observed everything that happened during the learning process.

4. Reflection stage

Obstacles in the learning process regarding project tasks in cycle I will be an improvement to continue to cycle II Cycle II

\section{Planning Stage}

At the planning stage, the preparation of learning tools needed during the teaching and learning process is carried out, including: (1) preparing learning materials in the form of videos that will be shared with more complicated stages, (2) Providing instructions for preparing the second stage of Adobe Flash application (3) prepared a list of activities in the implementation of Adobe Flash as a guide in action research.

2. Implementation Stage

This stage is the implementation of the learning scenarios that have been made in the previous stage in the classroom, including:

1) Initial activities

a. The researcher conditions the class (greetings, praying, filling out journals, attending and attending athletes.

b. Delivering a reflection on the implementation of learning using the Adobe Flash application in the first cycle which aims to achieve the target results in the implementation in the second cycle

c. Meeting 5, the researcher explains the material

2) Core Activities

a. Meeting 6.7, students implemented basic techniques using the Adobe Flash application but still paid attention to the frequency of time according to the researcher's command.

b. Meeting 8, researchers and students carry out practice test abilities

3) Final activity

a. Participants make conclusions about the learning process they have followed

b. Researchers provide reinforcement to the conclusions that have been conveyed

\section{Population and Sample}

\section{Population}

(Sugiyono, 2018) states that the population is a generalization area division consisting of objects/subjects that have certain characteristics and are in accordance with those determined by the researcher so that the researcher can then draw conclusions from these data. The population in this study were students who took handball lectures in the odd semester of the Physical Education Study Program, FKIP UNIB.

2. Sample 
The sample (Sugiyono, 2018) is part of the number and characteristics possessed by the population. The sample used in this study amounted to 24 students. The sampling technique used in this study is using a total sampling technique, this technique is a form of sampling technique, where all members of the population will be used as samples.

\section{RESULT}

Based On Research Conducted From June To December 2021 On 24 Physical Education Students From Fkip Unib Who Took The Handball Course With The Aim Of Improving The Learning Quality Of Third Semester Students Of Class B Fy 2021-2022 In The Orpil Handball Course By Using The Adobe Flash Application,

Discussion of Each Cycle

\section{a. Action Discussion}

Compared to the actions from cycles I, and II, there was a change in performing basic dribbling technique skills in Handball.

b. Discussion of Observation Results Compared to the observations, both the process and the results of cycles I and II experienced changes in terms of affective, psychomotor and cognitive, these changes experienced an increase in performing basic skills, both attitude, movement power, and skill power.

c. Discussion of Reflection Results

Compared to the reflection results from cycles I, and II, there was a change after being evaluated from the wrong movement, until it pointed to the right movement, from each cycle there was an improvement from the first cycle to the last cycle so that there was an increase.

\section{DISCUSSION}

Discussion and Conclusions The results showed that there was an increase in the ability of basic dribbling and passing skills on handball through the Adobe Flash player application, a test of basic dribbling and passing techniques was carried out in handball games. Overall, the research results show an increase as shown in the following graph.

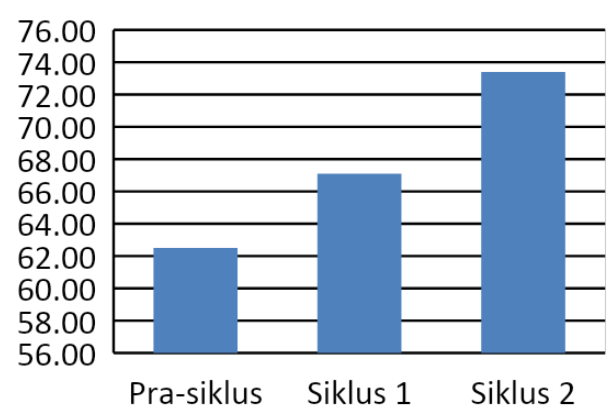

Graph 1.

From The Table And Graph Above, It Can Be Seen That There Is An Increase In Basic Dribbling Technique Skills Through The Practice Of The Online-Based Adobe Flash Player Application Method, Although There Are Students Who Have Not Finished In Cycle 2. The Ball Guard In The Pre-Cycle Of Students' Basic Technical Ability Has Not Increased, Only 7 People Have Completed From 24 Students With An Average Score Of 62.5. After Being Given Training Using The Adobe Flash 
Player Application Method With 1 Person Being The Ball Guard In Cycle 1, The Students' Basic Technical Abilities Increased, Although Only 12 People Were Said To Be Complete From 24 Students With An Average Score Of 67.10. From Tescycle Ii, 2 People Who Became Guards In Cycle 2, The Ability Of Basic Passing Techniques In Handball Is Increasing, As Evidenced By The Results Of The Study, 21 Students Were Said To Be Complete From 24 Students With An Average Score Of 73.40. The Increase Obtained From Pre-Cycle And Cycle 1 Is 5.40. Although There Are Still 12 Students Who Have Not Finished. And The Increase Obtained From Cycles I And Ii Is 6.30. Although There Are Still 3 Students Who Have Not Finished, In Cycle 2 It Has Been Proven That The Online-Based Adobe Flash Player Application Method Can Improve Passing And Dribbling Skills In Handball Games. Therefore, The Researcher Did Not Continue In Cycle 3 Because The Researcher Believed That The Students' Abilities Would Increase In Cycle 3.

\section{CONCLUSIONS}

Based on the research data that has been obtained and the results of data calculations, it can be concluded as follows:

1. Improvement of basic dribbling technique skills from before using the Online-Based Adobe Flash player Application method and after using the Adobe Flash player application method game in the pre-cycle, which is proven that there is no improvement because the
Adobe Flash player application method has not been applied $29 \%$ of 7 students who got a complete score of 24 students based on the details of the percentage of scores (A) 0 people, (B) 7 people, (C) 13 people, with no guards.

2. There was an increase in the first cycle, which was proven to be an increase of $50 \%$ of the 12 students who got a complete score from the total of 24 students based on the details of the percentage of scores (A) 0 people, (B) 12 people, (C) 12 people, using Adobe Flash player application method with 1 person being the guard. There was an increase from the Pre-cycle, which was a $21 \%$ increase with completeness from 7 students to 12 students who completed learning Handball.

3. In cycle II there was an increase in dribbling and passing skills in the Handball game using the Adobe Flash player application method with 2 students being guards. It is evident from the results of the study with an increase of $54.4 \%$ completed from cycle I which only $50 \%$ completed from 24 students with details of (A) 8 people, (B) 13 people, (C) 3 people. There was an increase from the first cycle, namely $37.5 \%$ increase with completeness from 12 students to 21 students who completed learning Handball from 24 students.

\section{SUGGESTION}

1. For further research, it is hoped that in applying the Adobe Flash player application method to the Handball orpil, it is hoped that the lecturer can develop the Adobe Flash player application method to be even better with some additional 
modifications so that Handball learning about basic dribbling and passing techniques can be maximized.

2. Lecturers can use the Adobe Flash player Application Method in other courses that are practical in the field during the physical distancing era.

\section{REFERENCES}

Agus Suprijono. (2014). Cooperative Learning. Yogyakarta: Pustaka Pelajar.

Ahmad, Susanto. (2016). Teori Belajar \& Pembelajaran Di Sekolah Dasar. Jakarta: Prenada Media Group.

Andi, S. (2016). Upaya Meningkatkan Kemampuan Menggiring Bola Dalam Permainan Sepakbola Melalui Metode Bermain Pada Siswa Putra Kelas Xi Tkbb Smk Negeri 1 Rasau Jaya Kabupaten Kubu Raya. Journal Of Chemical Information And Modeling, 53(9), 1689-1699.

Asyhar, Rayandra. (2012). Kreatif Mengembangkan Media

Pembelajaran. Jakarta: Referensi Jakarta.

Baskoro, D. A. (2016). Journal Of Physical Education , Sport , Health And Recreations.Journal Of Physical Education, Sport, Health And Recreation, 5(3), 2-5.

Berlianty, T. D. (2015a). Aplikasi Pembelajaran Mari Mengenal Waktu Sebagai Alternatif Pembelajaran Untuk Anak Kelas Satu Sekolah Dasar. Doctoral Dissertation, 1-24.

Berlianty, T. D. (2015b). Aplikasi Pembelajaran "Mari Mengenal Waktu" Sebagai Alternatif Pembelajaran Untuk Anak Kelas Satu Sekolah Dasar. Widyatama University Library, 1-24.
Candrawati, Y. (2018). Kinestetik: Jurnal Ilmiah Pendidikan Jasmani,2 (1) 2018. Issn 2477-331x. Evaluasi Program Pembinaan Prestasi Olahraga Bola Voli Pada Smk Negeri Di Kota Bengkulu Yunita, 2(1), 1.

Dr. Juliansyah Noor, S.E., M. M. (2017). Metodologi Penelitian. Jakarta: Perpustakaan Nasional.

Faozi, F., \& Rahmawati, D. (2019). Pengaruh Penggunaan Aplikasi Adobe Flash Terhadap Peningkatan Vo2max Pada Pemain Ekstrakurikuler Futsal Putri Man 1 Kabupaten Sukabumi. Jurnal Ilmiah Fakultas Keguruan Dan Ilmu Pendidikan, 5(02), 181-187. Https://Doi.Org/10.35569/Biormatika. V5i02.519

Ginting, S. S. (2019). Kinestetik: Jurnal Ilmiah Pendidikan Jasmani, 3 (1) 2019 Issn:2477-331x. Jurnal Ilmiah Pendidikan Jasmani, 3(1).

Gunawan, Y. R., Suherman, A., \& Sudirjo, E. (2016). Dribbling Bola Futsal Pada Atlet O2sn Kecamatan Sumedang Utara. 1(1), 1-12.

Hariyanto, A. A., \& Irawan, R. J. (2017). Peningkatan Daya Tahan Aerobik Melalui Pengembangan Latihan Fartlek Pada Ssb Anak Bangsa Surabaya Usia 15 - 16 Tahun Achmad Alfin Hariyanto Roy Januardi Irawan. Jurnal Kesehatan Olahraga, Vol. 05(03), 9-16.

Herbert Wagner, Thomas Finkenzeller, Sabine Wirth And Serge P. Von Duvillard. (2014). "Individual And Team Performance In Team-Handball: A Review". Journal Of Sport Science \& Medicine 13 (4), 808, 2014.

Jihad, Asep Dan Abdul Haris. (2012). Evaluasi Pembelajaran.Yogyakarta : Multi Pressindo. 
Kemenpora. (2014). Juklak Tes Dan Evaluasi Perkembangan Hasil Pplp/Sko/Pplm. Jakarta Pusat: Deputi Bidang Pembudayaan Olahraga.

Lhaksana, J. (2011). Taktik \& Strategi Futsal Modern. Jakarta: Be Champion.

Listiandi, A. D., Kusuma, M. N. H., Budi, D. R., Hidayat, R., Bakhari, R. S., \& Abdurahman, I. (2020). Pemanfaatan Aplikasi Smartphone Untuk Meningkatkan Daya Tahan. Jendela Olahraga, 05(2), 9-17.

Pujianto, A. (2015). Profil Kondisi Fisik Dan Keterampilan Teknik Dasar Atlet Tenis Meja Usia Dini Di Kota Semarang. Journal of Physical Education Health And Sport, 2(1), 3842.Https://Doi.Org/10.15294/Jpehs.V $2 \mathrm{i} 1.3941$

Rahmad, H. A. (2016). Pengaruh Penerapan Daya Tahan Kardiovaskuler (Vo2max) Dalam Permainan Bola Tangan Ps Bina Utama. Journal Of Teaching And Learning, 1(2).

Raibowo, S., Adi, S., \& Hariadi, I. (2020). Efektivitas Dan Uji Kelayakan Bahan Ajar Tenis Lapangan Berbasis Multimedia Interaktif. Jurnal Pendidikan: Teori, Penelitian Dan Pengembangan, 5(7), 944-952. Https://Doi.Org//10.17977/Jptpp.V5i7 .13726

Rinaldi, M., \& Rohaedi, M. S. (2020). Jago Futsal. Tangerang Selatan: Cemerlang. Rosita, T., \& Fachrezzy, F. (2019). Pengaruh Keseimbangan , Kekuatan Otot Tungkai Dan Koordinasi Terhadap Ketepatan Shooting Futsal. Jurnal Terapan Ilmu Keolahragaan, 4(2), 117-126.

Satria, H. M., \& Desandra, M. (2016). Pengaruh Latihan Power Otot Tungkai Terhadap Peningkatan Tendangan
Jarak Jauh Bola Tangan. Jurnal Ilmiah Bina Edukasi, 9, 3-12.

Satria, M. H. (2018). Pengaruh Latihan Circuit Training Terhadap Bola Tangan Universitas Bina Darma. Jurnal Ilmiah Bina Edukasi, 11(1), 3648.

Sugiono. (2011). Metode Penelitian Kuantitatif, Kualitatif, Dan R\&D. Penerbit Alfabeta Bandung.

Sugiyono. (2018). Metode Penelitian Kuantitatif, Kualitatif Dan R\&D. Bandung: Alfabeta.

Warni, H., Arifin, R., \& Bastian, R. A. (2017). Pengaruh Latihan Daya Tahan (Endurance) Terhadap Peningkatan Vo2max Pemain Bola Tangan. Jurnal Pendidikan Jasmani Dan Olahraga, 16. Zhannisa, U. H., \& Sugiyanto, F. (2015). Model Tes Fisik Pencarian Bakat Olahraga Bulutangkis Usia Dibawah 11 Tahun Di Diy. Jurnal Keolahragaan, 3(1), 117- 126. Https://Doi.Org/10.21831/Jk.V3i1.49 74 